\title{
Dzieje biblioteki I Liceum Ogólnokształcącego im. ks. Stanisława Konarskiego w Rzeszowie w latach 1658-1965
}

\begin{abstract}
Tedna z najstarszych szkół w Polsce - I Liceum Ogólnokształcące im. ks. Stanisława Konarskiego w Rzeszowie do tej pory doczekała się a kilku poważniejszych publikacji. Józef Świeboda przedstawił jej dzieje. ${ }^{1}$ Stanisław Pigoń zbadał działalność teatru konwiktowego w Rzeszowie. Tylko dzieje biblioteki szkolnej nie doczekały się jeszcze syntetycznego opracowania, istnieją bowiem tylko dwie prace przyczynkarskie jej dotyczące. Jedna Mieczysława Adamowskiego podająca w bardzo skondensowanej formie kilka najważniejszych wydarzeń z dziejów biblioteki ${ }^{2}$ i druga pozostająca w rękopisie praca bibliotekarki szkolnej Jadwigi Lippman, nie dokończona. ${ }^{3}$
\end{abstract}

Za podstawę opracowania historii biblioteki szkolnej posłużyły zachowane prawie w całości dokumenty szkolne przechowywane w Wojewódzkim Archiwum Państwowym w Rzeszowie. Cenne okazały się również drukowane sprawozdania szkolne z lat 1851 - 1958, przechowywane w Bibliotece Głównej Wyższej Szkoły Pedagogicznej w Rzeszowie.

I Liceum Ogólnokształcące im. ks. Stanisława Konarskiego w Rzeszowie jest jedną z najstarszych szkół w Polsce. Losy szkoły ściśle związane są $\mathrm{z}$ zakonem oo. Pijarów, jako że w czasach staropolskich procesem edukacji zajmowali się prawie wyłącznie duchowni. Zakon oo. Pijarów założony został przez Józefa Kalasancjusza (1556-1648) w Rzymie w 1617 roku $^{4}$ Jego głównym celem było kształcenie młodzieży, a nauki udzielano bez dyskryminacji stanowych. Ujęty ich postępowaniem Władysław IV Waza sprowadził zakon do Polski. Pierwszy konwent pijarski otwarto w Warszawie w 1642 roku i w tym samym roku drugi w Podolińcu. Trzeci dom założono w Rzeszowie ${ }^{5}$ w wyniku starań Jerzego Sebastian Lubomirskiego (1616-1667) wielkiego marszałka i hetmana koronnego.

Do powstanie tej szkoły wstępnie przyczyniła się Zofia Pudencjanna (zm. 1649), córka Mikołaja Spytka Ligęzy pana na Rzeszowie, która Z Badań Nad Polskimi Księgozbioram Historycznymi t. 21, Warszawa 2003. 
w swoim testamencie zapisała 57 tysięcy florenów polskich wraz z budowanym kościołem (1644-1649) i wznoszonym budynkiem konwentu dla sióstr klarysek. Po niej majątek przeszedł na jej siostrę Konstancję, żonę Jerzego Sebastiana Lubomirskiego. Na skutek zamieszania w trakcie wojen szwedzkich klasztor i kościół stały puste. Lubomirski obsadził w klasztorze w 1654 roku pijarów wyrzuconych przez Szwedów z Ołomuńca. Mieli zamieszkiwać klasztor tylko gościnnie. Jerzy Sebastian Lubomirski, wykonawca testamentu Zofii Pudencjanny, postanowił zmienić jej fundację i przekazać klasztor pijarom.

Dnia 10 listopada 1657 roku papieski Sekretariat Stanu wystawił upoważnienie do przejęcia fundacji w Rzeszowie przez Kongregację Generalną w Rzymie i powiadomił o tej decyzji Lubomirskiego. Zajęcia rozpoczęły się 12 marca 1658 roku. ${ }^{6}$ Jerzy Sebastian Lubomirski czynił starania u najwyższych władz kościelnych o zmianę testamentu Zofii Pudencjanny. Po jego śmierci starania te kontynuował syn, Hieronim Augustyn Lubomirski (1647-1706), marszałek i hetman wielki koronny, właściciel Rzeszowa. Efektem tych starań była wydana przez papieża Klemensa IX bulla In iuncti nobis devinitis Pastoralis... z 20 marca 1668 roku, która zezwalała nas objęcie fundacji. Dokument ten stanowi akt erekcyjny kolegium rzeszowskiego. ${ }^{7}$

W latach 1717-1738 jednym z nauczycieli tej szkoły był Stanisław Konarski (1700-1773), późniejszy reformator szkolnictwa pijarskiego w latach 1741-1754.

W pierwszych latach swojego istnienia szkoła nosiła nazwę „Collegium Lubomirscianum” (lata 1658-1788). Po pierwszym rozbiorze kolegium pijarskie zostało przekształcone w 1786 roku w niemieckie, świeckie państwowe gimnazjum i jako takie funkcjonowało pod nazwą ,Cesarsko-Królewskie Gimnazjum" aż do roku 1918.

Przewrót polityczny, zrzucenie panowania austriackiego w Rzeszowie i ogłoszenie przez miasto swej przynależności do niepodległej Polski umożliwiły przekształcenie się szkoły w państwowe polskie gimnazjum.

I Gimnazjum w Rzeszowie podporządkowane zostało Ministerstwu Wyznań Religijnych i Oświecenia Publicznego i weszło w stadium integracji ze szkołami z pozostałych zaborów. Dopiero reforma z 11 marca 1932 roku dokonała unifikacji szkolnictwa polskiego i w jej ramach przekształcono rzeszowską szkołę w czteroletnie gimnazjum i dwuletnie liceum typu humanistycznego. Zmieniła się też nazwa szkoły na „I Państwowe Gimnazjum i Liceum im. ks. Stanisława Konarskiego w Rzeszowie". ${ }^{8}$ Wojska 
niemieckie wkroczyły do Rzeszowa 9 września 1939 roku i zajęły budynek szkoły, niszcząc sprzęt, pomoce naukowe i część księgozbioru. Pierwszy po wojnie rok szkolny zainaugurowano 1 września 1944 roku. Organizację gimnazjum i liceum oparto na przedwojennym systemie. Dopiero ustawa z 15 lipca 1961 roku wprowadziła reformę oświaty, przekształcając w roku szkolnym 1966/1967 szkołę w czteroletnie gimnazjum.

\section{Dzieje biblioteki szkolnej}

Wraz z kolegium rzeszowskim powstałym w 1658 roku utworzona została biblioteka. Jej istnienie zainicjował Onufry Conti (1606-1686), prowincjał w Mikołowie na Morawach, twórca pijarskich bibliotek klasztornych, razem z pierwszym rektorem kolegium Wacławem Opatowskim. Fundator szkoły Jerzy Sebastian Lubomirski miał ponoć przekazać na ten cel „wóz pełen książek".

Z księgozbioru biblioteki korzystali zapewne (1606-1686), nieliczni użytkownicy prawdopodobnie ze względu na jego specyfikę przystosowaną do potrzeb młodzieży i zakonników. Od początku istnienia biblioteka niewiele się rozrosła licząc w końcu XVII wieku 887 pozycji. Wzbogacono ją dopiero w następnym stuleciu, tak, że przez bibliofilów zaliczana była do znaczniejszych w Polsce. ${ }^{9}$

Reformator szkolnictwa pijarskiego Stanisław Konarski w swoich Ustawach szkolnych rozważał problem bibliotek szkolnych i czytelnictwa uczniów, jako istotnych elementów dydaktyki i wychowania. Zalecał nauczycielom szkół pijarskich rozwijanie u młodzieży zamiłowania do lektury, każdy profesor zobowiązany był, bowiem do wskazywania wychowankom odpowiednich książek w zakresie swojej specjalności, a generalni przełożeni klasztoru mieli corocznie pomnażać zbiory biblioteki szkolnej przedstawiając prowincjałowi w czasie wizytacji szkoły spis nowo zakupionych pozycji. Odpowiedzialność za porządek w bibliotece i konserwację książek ponosili rektorzy i wychowawcy. Oni też wyznaczali spośród siebie bibliotekarza do pilnowania, aby nikt nie zabrał książki bez zanotowania jej w spisie wypożyczeń. ${ }^{10}$

Pijarzy rozpoczęli nauczanie w swoim kolegium dnia 19 marca 1658 roku. Informację taką przekazuje profesor gimnazjum rzeszowskiego Jan Danielski (1884-1984) w rozprawie szkolnej zamieszczonej w Sprawozdaniu Dyrekcji I Liceum i Gimnazjum... z roku 1944/1945.." Danielski oparł swoją tezę na wynikach badań innego nauczyciela rzeszowskiej szkoły, Fi- 
lipa Świstunia ogłoszonych w sprawozdaniu szkolnym za lata $1885 / 1886^{12}$ oraz na źródłach rękopiśmiennych Biblioteki Czartoryskich w Krakowie, odnoszących się do pijarów rzeszowskich. ${ }^{13}$

Danielski w swojej pracy podaje dwa szczegóły dotyczące biblioteki pijarskiej zaczerpnięte z Kroniki... Świstunia: „Konwikt posiadał piękną bibliotekę, którą gubernium rozporządzeniem z 2.0 kwietnia 1789 roku poleciło odesłać do Lwowa dla pomnożenia zbiorów naukowych nowo założonego uniwersytetu. Prefekt gimnazjum zwlekał z wykonaniem tego rozporządzenia, widocznie w nadziei ocalenia tego cennego skarbu dla swego zakładu, dopiero na ponowne naglenie wysłał w maju 1792 roku szesnaście pak książek do wszechnicy lwowskiej. Ponieważ bibliotekę wszechnicy dotknął pożar w 1848 roku, w czasie, którego spłonęło czterdzieści tysięcy tomów wraz $\mathrm{z}$ inwentarzami, to niepodobna dociec, ile tomów i jakie dzieła z biblioteki popijarskiej wysłano do Lwowa. Część biblioteki sprzedano przedtem w roku 1788, 9 czerwca, na aukcji publicznej z nakazu gubernium, a uzyskane pieniądze obrócił rząd również na uposażenie biblioteki uniwersyteckiej. Przy tej sposobności sprzedane zostało prawdopodobnie archiwum pijarskie wraz z dokumentami i rękopisami". ${ }^{14}$

Pijarzy posiadali dzieła z zakresu przedmiotów nauczania, ,jest na to w obecnej bibliotece nauczycielskiej jeden dowód pośredni. Mianowicie pod numerem $207 \mathrm{w}$ grubym tomie pism Cycerona wydanym w Hamburgu w 1619 roku jest na stronie 462 wewnętrzna karta tytułowa Penu Tullianum, a na niej adnotacja „Bibliothecae Domus Ressoviensis Scholarum Piarum reparatus 1779". A zatem dzieło to mieli pijarzy w wieku XVII lub XVIII w swej klasztornej bibliotece, potem im zaginęło, aż w roku 1779 odzyskali je" - pisze dalej w swojej rozprawie Danielski. Na jego wnioski powołuje się dyrektor gimnazjum Mieczysław Adamowski, autor pracy przyczynkowej do historii biblioteki szkolnej. ${ }^{15}$

W zakładzie rzeszowskim po wspomnianej wcześniej licytacji pozostało zaledwie sześćdziesiąt zużytych popijarskich woluminów. ${ }^{16}$ Potwierdzenie tego można znaleźć w starych aktach szkolnych, odnoszących się do inwentarzy bibliotecznych $\mathrm{z}$ lat 1824-1867. Znajduje się w nich informacja dyrektora gimnazjum Józefa Bieleckiego z dnia 22 października 1842 roku, że prefekt Jan Melicher (1783-1840) pozostawił sześćdziesiąt starych łacińskich książek z XVI, XVII i XVIII wieku, które zupełnie zniszczone i nienadające się do użytku szkolnego przejął od swojego poprzednika, zastępcy dyrektora Daniela Czabinaya w sierpniu 1811 roku. Książki te dyrektor Bielecki przeznaczył na makulaturę. ${ }^{17}$ Inventarium über die dem 
Rzeszower Gymnasium gehörigen Schuleinrichtüngstïcke, Gerätschaften, Bücher und wissenschaftlichen Sammlungen założone przez Franciszka Wassurê, prefekta w latach 1830-1840, dnia 5 marca 1839 roku, a przekazane przez niego w dniu 22 sierpnia 1840 roku zastępcy dyrektora Wincentemu Hoffmanowi i w dniu 17 października 1841 roku dalej przekazane Józefowi Bieleckiemu, zawiera w dziale „D” wykaz książek przejętych przez Melichera w 1811 roku, których spis wykazuje te właśnie sześćdziesiąt książek. ${ }^{18} \mathrm{Na}$ końcu tego spisu znajduje się adnotacja Melichera: „Z wyżej wymienionych książek ledwie jedna lub druga zupełna i cała, a wszystkie do tego stopnia są nadwyrężone używaniem i starością, że zaledwie zasługują na miejsce i przechowywanie”, się jeszcze dopisek Bieleckiego: „ponieważ wymienione książki są bez jakiejkolwiek wartości i nie do użycia, należy je potraktować jako makulaturę...".

Były dyrektor gimnazjum Mieczysław Adamowski, opiekujący się w latach 1948-1949 biblioteka, znając te dokumenty stwierdził:"... innych konkretnych śladów z dawnej biblioteki pijarskiej w obecnej bibliotece nauczycielskiej nie znalazłem, chociaż sporo jest dzieł z wieku XVII i XVIII.""19

Trudno jest więc ustalić, kto zajmował się biblioteką i prowadzeniem inwentarzy, bo takie istnieć musiały dla orientacji w posiadanym zbiorze, tym bardziej, że wiadomo o jego udostępnianiu poza szkołą i klasztorem.

Marian Szewera, opiekun biblioteki nauczycielskiej w latach 1925-1931 w kwestionariuszach dotyczących biblioteki rozesłanych przez Departament Nauki i Szkół Wyższych przy Ministerstwie Wyznań Religijnych i Oświecenia Publicznego, podaje jako datę powstania bioblioteki nauczycielskiej rok $1782 .{ }^{20}$ Nie wiadomo na jakich źródłach Szewera oparł swoją tezę, bowiem nie udało się odnaleźć żadnego innego dokumentu z taką data. Wiadomo, że w tym właśnie roku nastąpiła kasata kolegium rzeszowskiego przez władze austriackie.

W okresie pijarskim wydatki na bibliotekę były umiarkowane i wzrosły dopiero w następnym stuleciu, kiedy księgozbiór zaliczano już do znaczniejszych w kraju. ${ }^{2 !}$ Brak jednak konkretnych danych liczbowych, podobnie jest $\mathrm{z}$ informacjami o umiejscowieniu biblioteki w budynku konwentu, jej lokalu i wyposażeniu.

Sprawami księgozbioru zaczęto zajmować się od czasu wprowadzenia planu Langa dla szkolnictwa średniego w Galicji w 1811 roku. Na jego podstawie władze szkolne wydały szczegółowe spisy książek, okazów i przyrządów, jakie powinny znajdować się w bibliotece i gabinetach. ${ }^{22} \mathrm{~W}$ tedy też zaczęto gromadzić pierwsze książki. Od 1816 roku wszystkie gim- 
nazja były zobowiązane do tworzenia własnych księgozbiorów. Na ten cel Nadworna Komisja Naukowa przeznaczała dla każdego gimnazjum rządowego corocznie przez sześć lat 200 guldenów. W następnych latach szkoły miały otrzymywać $z$ funduszu naukowego po 50 guldenów. Była to suma nieduża i niewiele można było za nią kupić. Dlatego w 1830 roku znajdowało się w bibliotece zaledwie 11 książek, w tym 60 stanowiły zużyte popijarskie przeznaczone na makulaturę. ${ }^{23}$

W roku 1824/1825 za prefektury Jana Melichera zaczęto tworzyć bibliotekę gimnazjalna. Gubernium we Lwowie przekazało na ten cel w latach 1824-1830 w siedmiu przesyłkach książki z księgarni Kuhna i Milikowskiego we Lwowie. Na podstawie Wysokiego Zarządzenia Gubernium z dnia 18 kwietnia 1835 roku zakupiono za lata 1832-1836 jeszcze trzynaście pozycji. Akcję tę powtórzono w latach 1837-1841. Łącznie za okres siedemnastu lat zakupiono 89 książek. Z roku szkolnego 1840/1841 zachował się katalog rzeczowy książek, który wykazuje łącznie 109 pozycji. W kolejnych latach starano się systematycznie nabywać dzieła do biblioteki szkolnej. Ilość zakupionych pozycji uzależniona była od kwoty funduszy posiadanych przez szkołę od skarbu państwa.

Bibliotekarzami od początku aż do roku 1848 byli prefekci szkoły ewentualnie ich zastępcy. Dopiero 10 grudnia 1848 roku stanowisko to, objął z ramienia grona pedagogicznego, profesor nauk przyrodniczych Czesław Łoziński. Dzięki jego zabiegom powstał poważniejszy księgozbiór szkolny. Z inicjatywy grona nauczycielskiego Ministerstwo Oświaty zezwoliło, aby ,...powstała przy C.K. Gimnazjum w Rzeszowie biblioteka dla użytku młodzieży i nauczycieli z darów dobrowolnych w pieniądzach, książkach $\mathrm{i}$ innych przedmiotach do nauk przyrodniczych służących". ${ }^{24} \mathrm{~W}$ odpowiedzi na dwie odezwy grona nauczycielskiego z 1848 roku z terenu całej Galicji nadchodziły dary dla biblioteki uczniowskiej. Spis darowizn obejmuje okres od 10 grudnia 1848 roku do 25 lipca 1852 roku i wykazuje 1051 pozycji. W archiwaliach szkolnych z tego okresu zachowały się nawet oryginalne listy ofiarodawców. Oprócz książek zebrano także pieniądze na ich zakup. Sprawozdanie roczne dyrekcji za rok szkolny 1850/1851 wykazuje 1167 dzieł w 2215 tomach, z czego za dotację skarbową, kwocie 200 florenów rocznie, kupiono 157 dzieł w 515 tomach, za pieniądze zebrane w latach 1849-1851, w kwocie 191,31 florenów kupiono 187 dzieł w 227 tomach, w darze otrzymano 823 pozycje w 1423 tomach od 69 ofiarodawców. ${ }^{25} \mathrm{Ak}$ cja ta zapoczątkowała istnienie biblioteki uczniowskiej. 
Dnia 1 września Czesław Łoziński został przeniesiony do Tarnopola, a bibliotekę przejęli ponownie dyrektorzy gimnazjum, bo dopiero w roku szkolnym 1886/1887 pojawia się w sprawozdaniu szkolnym nazwisko bibliotekarza z ramienia grona pedagogicznego, Ludwika Kozakiewicza. Od roku 1851 brak bliższych informacji o bibliotece aż do roku 1876, kiedy to jej zasób wynosił 1346 dzieł w 3454 tomach. Była to już dość zasobna biblioteka. W jej zbiorach najliczniejszą grupę stanowiła literatura klasyczna oraz opracowania z zakresu historii i geografii. Księgozbiór był zaopatrzony słabiej w literaturę polską.

Pierwsze uregulowanie prawne dotyczące sprawy księgozbiorów pochodzi z 1850 roku i jest nim Instrukcja o wypożyczaniu książek z bibliotek uniwersyteckich i gimnazjalnych. ${ }^{26} \mathrm{Kolejnym}$ uregulowaniem dotyczącym samej organizacji biblioteki była Ustawa zasadnicza $z$ dnia 2 grudnia $1867 .{ }^{27}$ Ustawa oddawała sprawę nadzoru nad biblioteką w ręce dyrektora szkoły. Bezpośredni nadzór nad zbiorami środków naukowych, które należały do danego przedmiotu oddawano nauczycielom tych przedmiotów. Ustawa nakazywała podział biblioteki na nauczycielską i uczniowską. „Do biblioteki nauczycielskiej należy kupować takie dzieła, których nauczyciele potrzebują do postępu w swojej wiedzy i gruntownego udzielania nauki, a których sprawienie przekracza możliwości finansowe poszczególnych nauczycieli... Zarząd biblioteki, nabywanie, układanie, katalogowanie książek, nadzór nad ich wypożyczaniem itd. sprawuje sam dyrektor albo poruczy go wyraźnie jednemu z rzeczywistych nauczycieli gimnazjum" ${ }^{\text {"28 }}$ Zadaniem biblioteki dla uczniów było udostępnianie uczniom utworów literatury klasycznej języka ojczystego oraz dzieła służące do nauki poszczególnych przedmiotów. Dopiero w roku 1886 wyznaczono w rzeszowskim gimnazjum jednego nauczyciela do opieki nad księgozbiorem. Podziału na bibliotekę nauczycielską i uczniowską dokonano już w roku szkolnym 1849/1850.

Uzupełnieniem ustawy było wydane przez Ministerstwo Wyznań i Oświaty, rozporządzenie z 14 czerwca 1878 roku o dotacji rocznej na zakup środków pomocniczych i naukowych. normalna dotacja roczna w ośmioklasowych gimnazjach wynosiła 440 złotych, z czego 200 przeznaczano na zakup książek dla biblioteki i środków pomocniczych do nauki geografii. Niewielkie nakłady finansowe wymuszały wcześniejsze podejmowanie decyzji o zakupie książek najpotrzebniejszych w bibliotece. Kolejne rozporządzenie z 16 grudnia 1885 roku nakazywało rewizje książek z bibliotek dla uczniów i usunięcie „książek obrażających poczucie religijne, moralne lub patriotyczne"29 
Rada Szkolna Krajowa z terenu Galicji również wydawała własne rozporządzenia prawne dotyczące bibliotek szkolnych. W 1872 roku polecono zakładać z uzyskiwanych darów osobne zbiory książkowe dla ubogich uczniów. ${ }^{30}$ Pierwsza wzmianka o takiej bibliotece w rzeszowskiej szkole pojawia się dopiero w 1898 roku.

Ważną rolę w historii rozwoju biblioteki gimnazjalnej odegrała fundacja Henryka Jakuba Kretschmera (1831-1874) byłego ucznia gimnazjum. Fundacja przetrwała do 1914 roku i została zamknięta z powodu wojny i dewaluacji pieniądza. Mieczysław Adamowski w notatce dotyczącej Kretschmera, a umieszczonej w Slowniku pracowników polskiej ksiażki podaje informacje, o tym, że fundacja znalazła się w Bibliotece Głównej WSP w Rzeszowie i liczy 600 tomów. Józef Świeboda twierdzi, że pozostawiono ją w szkole, gdzie w 1975 roku spłonęła z powodu nieuwagi uczniów. Biblioteka Główna WSP posiada inwentarz tej fundacji, ale jej pracownicy nigdy nie spotkali się książkami pochodzącymi z fundacji Kretschmera.

Wróćmy jednak do wieku XIX. W roku 1886 bibliotekę przejmują ponownie nauczyciele, jako pierwszy po wieloletniej przerwie obejmuje ją Ludwik Kozakiewicz i prowadzi ją do kwietnia 1895 roku. Brak jednak informacji o bibliotece, oczywiście poza danymi o jej zasobie. W latach 1898 i 1900 całość biblioteki nauczycielskiej została ujęta w katalogu działowym. Sporządził go opiekun bibliotek uczniowskich Emanuel Roszka i na polecenie Rady Szkolnej Krajowej opublikował w drukowanym katalogu zamieszczonym w sprawozdaniach szkolnych z lat 1898/1899 i 1899/1900. Katalog ten miał służyć lepszej orientacji w zawartości biblioteki nauczycielskiej, jednakże w następnym roku przeprowadzona została reorganizacja całego księgozbioru, tak, że wyłączono z niego biblioteki uczniowskie, wykreślono ubytki, a stan biblioteki nauczycielskiej z 6.288 dzieł zmniejszył się do 3.840 dzieł.

W roku 1905 uczniowie stworzyli własną organizację charytatywną pod nazwą „Bratnia pomoc”, która posiadała własną bibliotekę, jej zbiory udostępniano najbiedniejszym uczniom. ${ }^{31}$ Równolegle istniała „Czytelnia uczniów", w której dokonywało się samokształcenie z zakresu historii i literatury polskiej oraz niedzielne czytania dzieł literatury ojczystej.

Biblioteka nauczycielska udostępniała „Czytelni uczniów” na niedzielne spotkania czasopisma i bibliotekę podręczną. Z "Czytelni uczniów” mogli korzystać uczniowie czterech najwyższych klas. Czytelnia działała do roku 1918, kiedy jej cel samokształceniowy przestał mieć znaczenie wobec przywrócenia państwa polskiego. 
W ramach biblioteki uczniów funkcjonowały biblioteki niemiecka, ruska i polska. Dwie pierwsze liczyły po tysiąc tomów każda, ruska liczyła ich tylko 67 . Wynikało to $z$ faktu, że język ruski był przedmiotem nauczania w szkole rzeszowskiej dopiero od 1909 roku i na dodatek nadobowiązkowo. W okresie wojennym zniesiono stary podział bibliotek uczniowskich, zastępując go podziałem na bibliotekę uczniów młodszych i starszych. Sprawozdanie szkolne $\mathrm{z}$ roku 1920/1921 podaje zasób według starego podziału.

Stan pomocy naukowych i księgozbiór odziedziczony po czasach austriackich wzbogacano sukcesywnie w okresie międzywojennym. Biblioteka nauczycielska w 1918 roku liczyła 5.125 dzieł, a biblioteki uczniowskie 1.971 dzieł. Cała biblioteka była nieuporządkowana i dlatego jej stan liczbowy w następnych latach był trudny do ustalenia. Uporządkowano ją dopiero w 1925 roku przeprowadzając skontrum i wykreślając ubytki. W tym czasie biblioteka nauczycielska zawierała głównie dzieła naukowe, popularnonaukowe względnie dawne podręczniki szkolne w języku polskim, niemieckim, łacińskim i niewiele w języku francuskim, angielskim i włoskim, czasopisma naukowe, słowniki i encyklopedie. Mało było literatury pięknej. Umieszczano ją raczej w bibliotekach uczniowskich, jako zalecaną literaturę obok podręczników i powieści dla młodzieży. Przez cały okres swojego istnienia biblioteka gimnazjalna zasilana była darami osób prywatnych i instytucji naukowych. Dary te, szczególnie od Polskiej Akademii Umiejętności, Uniwersytetów w Wiedniu i Lwowie, decydowały o naukowym charakterze biblioteki nauczycielskiej. Była ona często warsztatem pracy nauczycieli różnych szkół średnich zobowiązanych do umieszczania w sprawozdaniach szkolnych rozpraw naukowych.

Bibliotekę rzeszowską zalicza się do jednych z większych bibliotek szkolnych w Galicji, obok bibliotek szkolnych w Wadowicach i Lwowie, które w latach 1905-1907 liczyły ponad 9 tysięcy tomów. ${ }^{32}$

Niemcy zajęli Rzeszów 8 września 1939 roku. Budynek szkoły przejął Sąd Miejski i Okręgowy. Dyrektor Mieczysław Adamowski razem z woźnym Franciszkiem Jakubem z narażeniem życia zdążyli jeszcze wynieść ze szkoły arkusze ocen i inne akta szkolne datowane od roku 1778. „Adamowski natrafiwszy wśród przełożonych Niemców na Austriaków, ukazał im stare, dziewiętnastowieczne akta, sprawozdania, druki, podręczniki i książki w języku niemieckim jeszcze z czasów, kiedy szkoła była pod panowaniem austriackim i w ten sposób uratował przed losem, jaki spotkał większość księgozbiorów w Polsce, to jest przed spaleniem" wspomina Tadeusz Bieda, były uczeń szkoły. Niemcy zamknęli akta i zbiory bibliotecz- 
ne w dwóch pomieszczeniach poklasztornych i opatrzyli napisem: „Nicht berühren! Eigentum des III Reiches". Udało się ukryć wiele bezcennych starodruków i dzieł literatury polskiej, które po zakończeniu działań wojennych wróciły do biblioteki szkolnej. Jednakże wojenne straty biblioteki w porównaniu ze stanem z roku 1939 (26.179 egz.) wyniosły 2.866 pozycji, co stanowiło $10 \%$ całego zbioru. Straty bibliotek uczniowskich wyniosły 932 pozycje na ogólną liczbę 4.211 pozycji.

Działalność biblioteki wznowiono już od września 1944 roku, jej opiekunem został Jan Danielski, biblioteki uczniów objęli: nauczyciel języka niemieckiego Mieczysław Perdeus (biblioteka niemiecka) i Wojciech Woś, nauczyciel języka polskiego (biblioteka polska). Bibliotekę czytelni uczniów włączono do polskiej biblioteki pod opieką profesora Wosia. Przyczyną tego stanu był brak lokalu w budynku szkolnym, dlatego ocalałe 759 dzieł w 822 tomach połączono z książkami biblioteki polskiej. Już w następnym roku szkoła zorganizowała zbiórkę książek. Zebrano łącznie dla biblioteki szkolnej 274 książki, z których 45 przesłano do Złotowa koło Piły w darze dla tamtejszej biblioteki.

W roku 1948 stan liczbowy biblioteki uległ zmianie w związku z usuwaniem z zasobów bibliotecznych literatury chrześcijańskiej i sanacyjnej. Nie oszczędzono też literatury dla młodzieży uznając, że jest zbędna w szkole średniej. W miejsce usuniętych pozycji otrzymano książki od Wydziału Oświaty Prezydium Wojewódzkiej Rady Narodowej i z przydziału Ministerstwa Oświaty oraz Polskiej Akademii Nauk.

$\mathrm{Z}$ bibliotek uczniowskich w niezmienionym stanie pozostawiono tylko bibliotekę polską z niemieckiej i ruskiej utworzono jedną bibliotekę językowa. Ostatecznie stan liczbowy i organizacja biblioteki uległy tak znacznym zmianom, że wszystkie istniejące w szkole księgozbiory połączono w 1950 roku w jeden i oddano pod opiekę nauczycielowi języka polskiego Edwardowi Kowalskiemu. Od 1 października 1951 roku zatrudniono etatową bibliotekarkę Jadwigę Lippman. Za jej kadencji utworzono ponownie w 1957 roku bibliotekę uczniowską. Jednocześnie księgozbiór starej biblioteki nauczycielskiej przejęła od roku 1959 filia Pedagogicznej Biblioteki Wojewódzkiej w Rzeszowie celem skatalogowania go, co opieszale wykonywał były dyrektor Mieczysław Adamowski, nie chcąc szkoły pozbawiać tego cennego zbioru. Na polecenie Kuratorium z dnia 9 grudnia 1960 roku księgozbiór oddano całkowicie w kompetencje Pedagogicznej Biblioteki Wojewódzkiej. ${ }^{33}$ 
Bibliotekę nauczycielską liczącą 12.248 woluminów, w tym wiele starodruków i 8.349 sprawozdań szkolnych w 1964 roku przekazano nowo powstającej Wyższej Szkole Pedagogicznej w Rzeszowie. Zachowane z okresu przedwojennego 915 książek z biblioteki polskiej, 759 z czytelni uczniów i 496 z biblioteki niemieckiej posłużyło za podstawę obecnej biblioteki szkolnej. ${ }^{34}$

Istnieją rozbieżności, co do liczby przekazanych książek. Józef Świeboda podaje dokładną liczbę przejętych przez WSP książek: 20.597 woluminów. Jadwiga Orzech szacuje ją na 22 tysiące książek. ${ }^{35}$ Brak oficjalnych protokołów zdawczo-odbiorczych i inwentarzy przekazanego zbioru uniemożliwia podanie dokładnej liczby przekazanych książek i sprawozdań. Wiadomo tylko, że inicjatorami pomysłu byli Franciszek Świder, ówczesny dyrektor Biblioteki Pedagogicznej i kurator oświaty Kazimierz Żmudka. Przyczyną najprawdopodobniej był fakt, że powstająca uczelnia musiała posiadać określoną liczbę książek we własnej bibliotece. Po przejęciu zbioru gimnazjalnego nadzór nad nim przejął pan magister Mieczysław Motyka. Na dzień dzisiejszy w bibliotece WSP w dziale „Zbiory specjalne" znajdują się 144 starodruki w 221 tomach (w 13 przypadkach w opisie katalogowym nie podano proweniencji rzeszowskiego gimnazjum). Trudno określić ogólną liczbę książek z XIX wieku, gdyż część z nich pozostaje nie opracowana w magazynach. Z przekazów świadków przenosin księgozbioru wiadomo, że zaginęło wiele cennych pozycji np. egzemplarze dzieł Jana Kochanowskiego wydanych jeszcze za życia autora, Sonety krymskie Mickiewicza z jego autografem.

Zastanawiający jest brak jakichkolwiek dokumentów określających ile i jakie książki przekazano. Podawana przez Świebodę liczba książek odpowiada liczbie dzieł w bibliotece nauczycielskiej w roku 1944 (5.300 w 12.248 tomach), wydaje się ona prawdziwa, gdyż w obecnej bibliotece szkolnej brak jakichkolwiek książek z okresu przedwojennego pochodzących z biblioteki nauczycielskiej. Biblioteka WSP opracowała tylko część z przejętych zbiorów, a mianowicie starodruki i około 1.400 druków z XIX wieku znajdujących się w dziale „Rara”. Pozostałe książki z XIX i początków XX wieku, według relacji pracowników biblioteki, prawdopodobnie leżą nieopracowane w magazynie. Mimo oficjalnego zakazu wypożyczania tych zbiorów, udostępnia się je studentom i wykładowcom. 
Działalność i funkcje biblioteki

\section{Gromadzenie zbiorów}

Biblioteka utworzona została z darów fundatora szkoły Jerzego Sebastiana Lubomirskiego. Brak archiwaliów dotyczących pijarów rzeszowskich nie pozwala określić, ile i jakie książki przekazał Lubomirski. Nie wiadomo również, jakie książki posiadali później pijarzy rzeszowscy, bowiem cały ich księgozbiór przekazany został nowo powstającemu uniwersytetowi we Lwowie w roku 1792, część biblioteki, jak już wspomniano, sprzedano wcześniej na aukcji publicznej.

Opierając się na zaleceniach Stanisława Konarskiego z jego Ustaw szkolnych można sądzić, że głównym źródłem napływu książek do biblioteki były zakupy zalecanych przez niego pozycji, przeznaczonych do nauki w konwentach pijarskich. ${ }^{36}$ Najprawdopodobniej część z nich pochodziła z działających w tym czasie pijarskich oficyn w Warszawie i Wilnie, gdzie kupowano inne, poza podręcznikowe zbiory trudno dziś ustalić.

Pierwsza pewna informacja o sposobie i źródłach doboru książek do biblioteki pochodzi z 1811 roku, kiedy to na mocy planu Langa wprowadzonego w Galicji dla szkolnictwa średniego, władze szkolne zaczęły wydawać szczegółowe spisy książek, okazów i przyrządów, jakie powinny znajdować się w bibliotece i gabinetach.

W roku 1816 wszystkie austriackie gimnazja zobowiązane zostały do tworzenia własnych bibliotek. Nadworna Komisja Naukowa przeznaczyła na ten cel 200 guldenów przez kolejnych sześć lat, a po ich upływie po 50 guldenów. Kwota ta nie była zbyt duża, tak, że do roku 1830 zakupiono za nią tylko 51 książek.

Od roku szkolnego 1824/1825 za prefektury Jana Melichera, Gubernium we Lwowie przekazało na rzecz biblioteki siedem przesyłek z księgarni Jana Fryderyka Kühna i Jana Milikowskiego we Lwowie, które łącznie zawierały w latach 1824 do 1830 pięćdziesiąt dziewięć książek. Wśród otrzymanych darów przeważały dzieła klasyków greckich i rzymskich stanowiących lekturę obowiązkową przy nauczaniu greki i łaciny, słowniki językowe. W następnych latach szkoła sama dokonywała zakupów zgodnie z zarządzeniem Gubernium i według sporządzonych przez nie spisów książek. W latach od 1832 do 1837 zakupiono u Kühna i Milikowskiego trzynaście dzieł i w roku szkolnym 1837/1838 jeszcze dziesięć. Pieniądze na ten cel uzyskano z Kasy Skarbowej w Rzeszowie na polecenie Gubernium, była to kwota 100 florenów. Wszystkich tych zakupów dokonywano posiłkując się 
nadal Wykazami ksiażek zalecanych do bibliotek szkolnych przesyłanymi do wszystkich szkół średnich.

Informacje o nowościach wydawniczych czerpano z przesyłanych bezpośrednio do szkoły katalogów wydawniczych i księgarskich. W archiwaliach szkolnych zachowały się katalogi firm z terenu monarchii austriackiej i Prus, proponujące podręczniki, słowniki i atlasy do użytku szkolnego. Najczęściej kupowano książki zalecane przez Ministerstwo Wyznań Religijnych i Oświaty, a od 1867 roku przez Radę Szkolną Krajową z siedzibą we Lwowie. Zarówno Ministerstwo, jak i RSK wydawały zarządzenia o wprowadzeniu do użytku szkolnego poszczególnych dzieł, do zakupu, których szkoła była zobligowana. W archiwaliach zachował się katalog firmy Heinricha Wilhelma Hahna Hahn'schen Buchhandlung in Hanover und Leipzig z kwietnia 1854 roku opatrzony dopiskiem „Zalecane przez Ministerstwo Wyznań Religijnych i Oświaty”. Innym źródłem informacji o nowościach były zawiadomienia o druku poszczególnych dzieł przesyłane wprost od wydawcy lub „Einladung zur Subscription” (zaproszenie do subskrypcji). Ministerstwo dokonywało selekcji proponowanych dzieł i wybrane wprowadzało obligatoryjnie do szkół zobowiązując je w ten sposób do nabycia dzieła. Dopiero przyznanie Galicji autonomii i utworzenie RSK zmieniło sposób doboru dzieł dla biblioteki szkolnej. Od tej pory grono nauczycielskie samo decydowało o zakupie książek według własnych potrzeb i o sposobie rozdziału środków przyznawanych na zakup pomocy naukowych. Od tej pory to właśnie zakupy stanowiły podstawowe źródło napływu książek.

Drugim sposobem uzyskania książek były dary od osób prywatnych i instytucji. Pierwsza wzmianka o darowiźnie na rzecz biblioteki pochodzi Z roku 1847/1848, kiedy to nieznana bliżej „obywatelka ziemska” pani Wojnarowska podarowała bibliotece osiemnaście książek. Liczba ofiarodawców wzrosła od roku 1848, kiedy to bibliotekarz Czesław Łoziński postarał się o zezwolenie Ministerstwa na powstanie biblioteki dla użytku młodzieży $z$ darów w pieniądzach i książkach. Jeszcze w tym samym roku Grono Pedagogiczne wystosowało do mieszkańców Rzeszowa odezwę: Geehrte Mitbürger i Szanowni Ziomkowie. W odpowiedzi na nie zaczęły napływać z terenu całej Galicji dary książkowe i pieniężne. Czesław Łoziński utworzył Spis darowizn obejmujący okres od grudnia 1848 roku do lipca 1852 roku, który wykazuje 1.051 pozycji książek oraz Spis chronologiczny dziel literackich dla księgozbioru Gimnazjum Rzeszowskiego przeznaczonych $\mathrm{z}$ lat 1848-1862 liczący 1.099 pozycji. ${ }^{37}$ 
Wśród ofiarodawców znaleźli się:

- Towarzystwo Gospodarskie Galicyjskie,

- hr. Józef Alfred Potocki z Łańcuta,

- hr. Edmund Krasicki z Liska,

- Czesław Loziński,

- Józef Bielecki, dyrektor Gimnazjum.

Poza książkami przesyłano do szkoły dary pieniężne. Ogółem zebrano 178 złotych reńskich, za które zakupiono dla biblioteki 133 tomy. Wśród otrzymanych darów dwadzieścia trzy pozycje pochodzą z XVI do XVIII wieku.

Regularnie otrzymywano dary od RSK i Akademii Umiejętności w Krakowie. W początkach XX wieku do ofiarodawców dołączył też Uniwersytet Jagielloński i Wydział Krajowy we Lwowie.

Od 21 listopada 1886 roku rzeszowskie Gimnazjum posiadało legat swojego byłego ucznia Henryka Jakuba Kretschmera w wysokości 1000 złotych reńskich rocznie, przeznaczony na zakup dzieł naukowych polskich do biblioteki szkolnej. W aktach szkolnych zachowało się pismo Magistratu Miasta Rzeszowa z dnia 5 maja 1887 roku o przekazaniu szkole szafy z napisem „Biblioteka gimnazjalna śp. Henryka Jakuba Kretschmera” i pieczątki z tym samym napisem. Wraz z otwarciem fundacji miasto przekazało szkole książki gromadzone przez Kretschmera. Warunkiem funkcjonowania tej fundacji było sporządzenie inwentarza otrzymywanych dzieł i coroczne zakupy polskich dzieł naukowych. ${ }^{38}$ Kuratorem Fundacji został Magistrat. W jego gestii pozostawał legat lokowany w papierach wartościowych. Fundacja przetrwała do roku 1914 i liczyła w chwili zamknięcia 542 pozycje w 769 tomach.

Specjalnością biblioteki były dzieła z zakresu filologii. Inwentarz działowy biblioteki z lat 1853-1856 podaje następującą zawartość poszczególnych działów:

- Literatura klasyczna

138 pozycji

- Literatura współczesna

58 pozycji

- Nauki przyrodnicze

91 pozycji

- Matematyka

57 pozycji

- Medycyna

27 pozycji

- Ekonomia

19 pozycji

- Geografia i historia

145 pozycji

- Gramatyka, słowniki, podręczniki językowe

178 pozycji

- Literatura polska

72 pozycje 
- Religia, filozofia, archeologia i sztuka

103 pozycje

- Literatura w języku francuskim

65 pozycji

Natomiast drukowany katalog samej tylko biblioteki nauczycielskiej przygotowany przez Emanuela Roszkę w latach 1899 do 1900 podaje zawartość księgozbioru nauczycieli w takich działach:

- Bibliografia

5 pozycji

- Filozofia i estetyka

111 pozycji

- Pedagogika i szkolnictwo

70 pozycji

- Umiejętności religijne

46 pozycji

- Filologia klasyczna, archeologia, epigrafika

200 pozycji

- poddział: gramatyka, stylistyka, metryka

40 pozycji

- Filologia nowoczesna:

a) język polski i inne słowiańskie

148 pozycji

b) język niemiecki

58 pozycji

gramatyka, stylistyka, poetyka

15 pozycji

- Lingwistyka

13 pozycji

- Geografia, etnografia, statystyka

37 pozycji

- Historia powszechna (oprócz austriackiej), nauki pomocnicze historii

141 pozycji

- Historia monarchii austriacko-węgierskiej i jej krajów

65 pozycji

- Matematyka

37 pozycji

- Historia naturalna

115 pozycji

- Fizyka, chemia, astronomia, meteorologia

32 pozycje

- Ekonomia, leśnictwo, gómictwo, rolnictwo i gospodarstwo domowe

24 pozycje

- Handel i komunikacja, przemysł

4 pozycje

Katalog ten obejmuje tylko wybrane, wartościowsze pozycje, bez podawania podręczników, słowników, encyklopedii, czasopism politycznych i literackich, szkolnych wydań klasyków literatury oraz publikacji Akademii Umiejętności z Krakowa. Profil gromadzenia zgodny jest typem szkoły i panującym w niej programem nauczania charakterystycznym dla gimnazjum klasycznego i nastawionym głównie na nauczanie przedmiotów humanistycznych. 
Brak archiwaliów z okresu pijarskiego ponownie uniemożliwia określenie sposobu opracowania zbiorów bibliotecznych. Można przypuszczać, że po reformie szkół pijarskich stosowano się do zaleceń Stanisława Konarskiego z jego Ustaw szkolnych. Konarski zaleca w nich sporządzanie corocznie spisów nowozakupionych książek oraz prowadzenie spisów wypożyczeń dla lepszej orientacji w posiadanym zbiorze.

Pierwsze potwierdzone informacje o sposobie opracowania zbiorów pochodzą z lat dwudziestych dziewiętnastego wieku. W roku 1827 założony został katalog akcesji książek ułożony w porządku alfabetycznym. ${ }^{39}$ Zapis inwentarzowy obejmuje następujące elementy: sygnaturę, nazwisko autora, tytuł, podział na części, adres wydawniczy i format. Katalog ten prowadzono do roku 1845. Jego uzupełnieniem był założony w 1840 roku katalog w następującym układzie działów:

Autorzy greccy

Autorzy rzymscy

Słowniki greckie, łacińskie i niemieckie

Książki pomocnicze do nauki języków i stylistyki

Klasycy niemieccy

Historia i geografia

Nauki przyrodnicze, historia naturalna i technologia

Religia

Miscellanea

środki pomocnicze do nauki geografii.

W obrębie każdego działu książki spisywano w porządku alfabetycznym według nazwisk autorów lub tytułów dzieł anonimowych, bądź zbiorowych. Zapis inwentarzowy jest dokładnie taki sam, jak w katalogu akcesji z 1827 roku. Dodatkowo stworzony został katalog alfabetyczny była bardzo starannie, na bieżąco wprowadzano informacje o ubytkach i ich przyczynie, posiadanych zbiorów. Sądząc z zapisów we wszystkich trzech katalogach, biblioteka prowadzona przestrzegano wpisywania wszystkich elementów opisu, co znacznie ułatwia identyfikację poszczególnych druków.

Po dopełnieniu zapisów w katalogu akcesji i katalogach alfabetycznym oraz rzeczowym, sygnaturę wpisywano na karcie tytułowej i na nalepce grzbietowej, obok sygnatury na karcie tytułowej umieszczano również pieczątkę biblioteki.

W 1845 roku sporządzono nowy katalog rzeczowy z zachowaniem dzia- 
łów w takim porządku, jak w katalogu z 1840 roku. Niestety, zapis pozostawia wiele do życzenia, częste są niepełne adresy wydawnicze i skrócone tytuły.

W trzy lata później następuje zmiana w sposobie zapisu nabywanych i otrzymywanych dzieł. Nowy bibliotekarz Czesław Loziński zakłada w miejsce katalogu akcesji, księgę darowizn i zakupów, w której skrupulatnie zapisuje datę, miejsce i cenę kupna, wartość darowizny oraz osobę ofiarodawcy. Jednocześnie przenumerowuje wszystkie książki i kataloguje je od nowa. ${ }^{40}$

Czesław Łoziński zakłada również dziennik podawczy „Zarządu biblioteki'. Od tej pory zasoby biblioteki zapisuje się w inwentarzu zdawczo-odbiorczym.

Cały księgozbiór nauczycielski podzielony jest na czternaście działów, bez podawania numerów dzieł. Niestety w aktach szkolnych ten inwentarz nie zachował się. Według informacji $\mathrm{z}$ akt $\mathrm{z}$ lat 1851-1853 w tym czasie przerobiono inwentarze założone przez Łozińskiego. Założono najprawdopopdobniej katalog działowy, składający się z jedenastu działów. Oddzielnie zapisywano czasopisma i książki dla biblioteki uczniów.

Jednostką inwentarzową zawsze jest całość dzieła ( wszystkie tomy, części lub zeszyty), niestety, w miarę przyrostu liczby książek w bibliotece szkolnej zapisów dokonywano mniej starannie, opuszczając adres wydawniczy, skracając tytuł. Wszystko to uniemożliwia dokładne ustalenie liczby woluminów będących w tym okresie w posiadaniu biblioteki.

Mimo odrębności księgozbioru uczniowskiego jego zasób opisywano w katalogach biblioteki nauczycielskiej w formie załącznika na końcu poszczególnych ksiag katalogu lub inwentarza. Wszystkie zapisy skracano w nim do niezbędnego minimum.

Dopiero w 1877 roku opracowano instrukcje prowadzenia inwentarzy. Były to dość dobre przepisy, które początkowo przeznaczone były dla bibliotek uniwersyteckich. W 1888 roku RSK nakazała wszystkim szkołom w Galicji wykonanie (bezpłatne) do 1890 roku trzech egzemplarzy inwentarzy szkolnych. Przesłano do szkół wzór formularza, który zawierał następujące pozycje: liczba bieżąca, nazwa i opis przedmiotu, ilość sztuk, rok i pozycja rachunku, cena kupna, wartość darowizny, ubytek i jego przyczyna oraz uwagi. Po jednym egzemplarzu inwentarza otrzymywali: zawiadowca biblioteki, dyrekcja szkoły i RSK. ${ }^{41}$ Przekazanie inwentarza RSK pozwalało na kontrolę realizacji zakupów zalecanych książek. Jednocześnie umożliwiało też orientację w zasobach poszczególnych bibliotek. Mimo swoistego rodzaju kontroli nad inwentarzami, nie dbano o ich poprawne wypełnia- 
nie zgodnie $z$ zaleceniami.

Począwszy od 1850 roku, na mocy rozporządzenia C.K. Ministerstwa Oświaty z dnia 31 grudnia 1850 roku, poszczególne gimnazja zaczęły wydawać programy szkolne w rzeczywistości będące sprawozdaniami z rocznej działalności szkoły. Każdy taki program, obok części z wiadomościami szkolnymi, zawierał przygotowaną przez jednego z nauczycieli szkoły, rozprawę naukową. Wszystkie gimnazja miały obowiązek wymiany między sobą sprawozdań, dlatego też biblioteka posiadała dużą ich ilość. W roku 1896/1897 ukazało się rozporządzenie o ogłaszaniu drukiem katalogów bibliotek nauczycielskich, ,aby umożliwić obszerniejsze korzystanie z bibliotek szkół średnich." ${ }^{42}$ Katalogi miały obejmować tylko wybrane wartościowe pozycje z pominięciem podręczników, słowników i encyklopedii, czasopism, szkolnych wydań klasyków literatury oraz publikacji Akademii Umiejętności z Krakowa. Katalog rzeszowskiej biblioteki nauczycielskiej ukazał się w latach 1899 i 1900, przygotował go ówczesny opiekun bibliotek uczniowskich Emanuel Roszka (1863-1932). Zasób biblioteki ujęty został w siedemnastu działach, a pozycje zakupione już po jego wydaniu umieszczono w „Dodatku”. Z nieznanych powodów opuszczono w katalogu działy czternasty i piętnasty. ${ }^{43}$

Utworzono następujące działy:

I. Bibliografia

II. Filozofia i estetyka

III. Pedagogika i szkolnictwo

IV. Umiejętności religijne

V. Filologia klasyczna, archeologia, epigrafika poddział: Gramatyka, metryka, stylistyka

VI. Filologia nowoczesna

a) język polski i inne języki słowiańskie poddział: gramatyka, stylistyka, poetyka

b) język niemiecki poddział: gramatyka, stylistyka, poetyka

VII. Lingwistyka

VIII. Geografia, etnografia, statystyka

IX. Historia powszechna (oprócz austriackiej), nauki pomocnicze historii $\mathrm{X}$. Historia monarchii austriacko-węgierskiej i jej krajów XI. Matematyka

XII. Historia naturalna

XIII. Fizyka, chemia, astronomia, meteorologia 
XIV. Rysunki, geometria wykreślna

$\mathrm{XV}$. Budownictwo, inżynieria ${ }^{44}$

XVI. Ekonomia, rolnictwo, ogrodnictwo, gospodarstwo domowe, leśnictwo

XVII. Handel, komunikacja, przemysł.

Opis zawiera nazwisko autora, jego imię lub inicjały, tytuł dzieła, adres wydawniczy, liczbę tomów oraz sygnatury. Każde dzieło oznaczone jest wyraźnie jednym słowem kluczowym, wyróżnionym w tekście pogrubioną czcionką. Słowem kluczowym jest bądź nazwisko autora bądź pierwszy rzeczownik tytułu w przypadku dzieł zbiorowych $i$ anonimowych oraz czasopism. Jednostką opisu jest zawsze całość dzieła bez względu na liczbę tomów i części. W niewielu przypadkach podany jest tłumacz lub kolejność wydania. Spis ten jest jedynym drukowanym wykazem zawartości biblioteki gimnazjalnej.

W latach 1901-1903 bibliotekę nauczycielską prowadził Julian Mazurek. Przeprowadził wtedy reorganizację inwentarza głównego i stworzył na potrzeby biblioteki odrębne przepisy. ${ }^{45}$ Od tej pory do inwentarza głównego należało wpisywać wszystkie dzieła przeznaczone dla biblioteki nauczycielskiej. Każde nowe dzieło otrzymywało kolejną liczbę porządkową dla dzieł uzupełnianych przybywającymi tomami liczbę porządkową zapisywano w rubryce „Uwagi” z dopiskiem „Ad nr...”. Obok inwentarza książkowego w bibliotece pojawił się pierwszy inwentarz kartkowy ułożony alfabetycznie według nazwisk autorów lub tytułów.

Zapis inwentarzowy obejmuje: liczbę porządkową, autora, skrócony tytuł $\mathrm{i}$ adres wydawniczy, ilość tomów, rok kupna, cenę, ubytek i jego przyczynę oraz uwagi dotyczące wykreślenia z inwentarza. Wedhug bieżącego porządku inwentarza ułożono księgozbiór nauczycielski, bez względu na przynależność do określonego działu nauki. Czasopisma zinwentaryzowano w osobnym wykazie. W praktyce ani sam Julian Mazurek, ani jego następcy nie stosowali się w pełni do nowych przepisów.

Kontynuację inwentarza z lat 1901-1903 stanowi inwentarz z lat 19251939, sporządzony przez Mariana Szewerę (1885-1964) po przeprowadzeniu dokładnego skontrum. ${ }^{46}$ Zmianom uległa forma zapisu inwentarzowego, wszystkie cechy identyfikacyjne książki umieszczono teraz w rubryce „Opis", przewidziano miejsce na wpisanie nazwiska ofiarodawcy i miejsce przechowywania dzieła.

Oba wyżej wymienione inwentarze obejmują 6.820 pozycji, niestety częste wykreślenia i dopiski nie pozwalają na dokładne określenie liczby dzieł 
znajdujących się w bibliotece nauczycielskiej. Sam Marian Szewera określił ją (w roku szkolnym 1925/1926) na 4.505 dzieł w 10.251 tomach. ${ }^{47}$

W myśl zarządzenia RSK z 1897 roku ,sporządzając nowy inwentarz biblioteki należy przeprowadzić ścisły rozdział pomiędzy biblioteką nauczycieli a biblioteką młodzieży i dla każdej z tych bibliotek sporządzić oddzielne inwentarze". ${ }^{48}$ W latach 1886-1922 prowadzono katalog książek z zakresu literatury niemieckiej, katalog książek historycznych w języku niemieckim oraz katalog działu matematyczno-fizycznego biblioteki niemieckiej dla uczniów. W taki sam sposób opracowano bibliotekę polską dla uczniów w latach 1927-1936. ${ }^{49}$

Dopiero w 1925 roku ukazał się okólnik Ministerstwa Wyznań Religijnych i Oświecenia Publicznego podający zasady prowadzenie bibliotek dla młodzieży szkół średnich, wymagał on prowadzenia katalogu alfabetycznego, a w większych bibliotekach również działowego. ${ }^{50}$ Do takiego katalogu należało wpisać wszystkie książki pod numerami zgodnymi z numerami w inwentarzu. W rzeszowskim gimnazjum tego typu katalogi istniały już na długo przed wejściem w życie okólnika.

Po dopełnieniu wpisu w inwentarzu głównym i katalogach, każdą z książek zaopatrywano w pieczęcie biblioteki i wpisywano czytelnie sygnatury na karcie tytułowej i ostatniej zadrukowanej stronie oraz na nalepce grzbietowej. Dla poszczególnych książek zakładano karly umożliwiające kontrolę wypożyczeń. Nie zachowały się nawet pojedyncze karty katalogu kartkowego biblioteki nauczycielskiej, karty książek z bibliotek uczniowskich wyrzucono tuż po wojnie, kiedy to kilkakrotnie łączono i dzielono księgozbiór gimnazjalny.

W sierpniu 1944 roku, po zakończeniu działań wojennych na terenie Rzeszowa, szkoła i biblioteka wznowiły działalność. Prace w bibliotece ograniczyły się do ustalenia liczby strat wojennych. W roku 1950 wszystkie zbiory połączono w jedną całość, lecz nie opracowano na nowo inwentarzy i katalogów. Dopiero w 1959 roku były dyrektor szkoły, Mieczysław Adamowski, na polecenie Kuratorium Oświaty miał skatalogować zbiór byłej biblioteki nauczycielskiej, co czynił powolnie w związku z planowanym przekazaniem księgozbioru nowo powstającej Wyższej Szkole Pedagogicznej w Rzeszowie. Do dziś przekazany wtedy zbiór pozostaje częściowo nieopracowany.

Własny inwentarz posiadała fundacja Henryka Jakuba Kretschmera, prowadzono go od chwili otwarcia fundacji w 1887 roku aż do roku 1914, kiedy to zamknięto ja, obejmuje on 543 pozycje. Fundacja posiadała też wła- 
sne pieczęcie do sygnowania książek. Jeden egzemplarz tego inwentarza zachował się w Bibliotece Głównej WSP w Rzeszowie.

Po dopełnieniu wpisu w księdze inwentarzowej i katalogach każdą z książek zaopatrywano w znak własnościowy. Sygnatury już od czasów pijarskich wpisywano odręcznie na stronie tytułowej dzieła, czasami już w preliminariach i na wyklejce, rzadko na końcu książki. W początkach istnienia biblioteki, kiedy księgozbiór był jeszcze niewielki sygnaturom nadawano formę cyfrową z numerem pozycji w księdze akcesji np. 503. Dopiero w miarę przyrostu księgozbioru numer akcesji poprzedzano skrótem określenia „numer” np. N, No. Od czasu podziału biblioteki na uczniowską i nauczycielska, książkom z biblioteki nauczycielskiej dopisywano przed sygnaturą skrót „B.N.”.

Po zmianie inwentarza w latach 1901-1903 wszystkie książki otrzymały nowe numery i dopisek „I.G." oznaczający, że sygnatura zgodna jest z numerem pozycji w inwentarzu głównym. Wszystkich poprawek dokonywano niebieskim ołówkiem.

W czasie istnienia biblioteki wielokrotnie zmieniano formę pieczęci szkolnych i bibliotecznych. Szkoły pijarskie w XVIII wieku używały pieczęci z orłem polskim i monogramem Najświętszej Marii Panny na jego piersiach oraz z nazwą szkoły: „Domus Ressoviensis Scholarum Piarum”. Niestety nie zachował się żaden egzemplarz książki pochodzący z tego okresu.

Trudno dziś ustalić dokładną chronologię pieczęci stosowanych w bibliotece. Najprawdopodobniej stosowano kilka pieczęci jednocześnie. Jedna $\mathrm{z}$ nich ma formę poprzecznie owalną zamiast obrazu w polu widoczny jest napis „Gymnazium w Rzeszowie”. Równolegle z nią używano pieczęci o formie tarczowej z zaokrąglonymi krawędziami dolnymi. Nad krawędzią górną znajduje się wieniec z liści. W polu umieszczono napis „K.K. Rzezower Gymnasium". Z tego samego okresu, wnioskując z używanej nazwy szkoły, pochodzi pieczęć herbowa podłużnie owalna. W jej polu znajduje się herbowy dwugłowy orzeł Habsburgów, obraz otacza legenda z napisem „K.K. Rzezower Gymnasium”.

Od czasu podziału biblioteki, dla biblioteki nauczycielskiej sporządzono pieczęć poprzecznie owalną z napisem w polu „Biblioteka Nauczycielska I Gimnazjum w Rzeszowie". Dla książek ze zbioru podręcznego dyrektora szkoły stosowano pieczęć podłużnie owalną herbową, z orłem Habsburgów i napisem w legendzie „Sigillum directoris C.R. (caesareum-regis) Gymnasii Ressoviensis". 
Wraz z uzyskaniem przez Galicję autonomii i wprowadzeniem języka polskiego do szkół i administracji zmieniono pieczęcie. Jedna z nich była typu monetowego o kolistej formie. W jej polu znajdował się orzeł habsburski, a w otoku umieszczono napis „C.K. Gimnazjum w Rzeszowie”. Druga $\mathrm{z}$ nich miała formę podłużnie owalną z herbowym orłem w środku pola i napisem w otoku „C.K. Gymnazium w Rzeszowie”. Najprawdopodobniej już po 1918 roku wprowadzono pieczęć typu monetarnego o obrazem orła polskiego w koronie znajdującym się w polu pieczęci i napisem krawężnym w otoku „I Państwowe Gimnazjum im. Ks. St. Konarskiego w Rzeszowie".

Osobną pieczęcią opatrywano książki z fundacji Kretschmera. Była to pieczęć kolista z napisem w legendzie „Biblioteka gimnazyalna w Rzeszowie”, a uzupełnia go napis w polu pieczęci „Fundacyi ś.p. Henryka Jakóba Kretschmera".

\section{Udostępnianie księgozbioru}

Z powodu braku archiwum pijarskiego niewiele wiadomo również o udostępnianiu księgozbioru. Józef Świeboda po przebadaniu źródeł z rzymskiego archiwum OO. Pijarów stwierdza, że księgozbiór udostępniano nawet poza szkołe, choć korzystały z niego przypuszczalnie wąskie kręgi użytkowników. ${ }^{51}$

Pierwsze pewne informacje o udostępnianiu książek $\mathrm{z}$ biblioteki pochodzą z roku 1850, kiedy ukazała się instrukcja regulująca tę kwestię. Wedhug zawartych w niej przepisów, prawo wypożyczania książek do domu mieli profesorowie uniwersyteccy i innych uczelni, docenci, nauczyciele, asystenci, adiunkci, suplenci (zastępca etatowego nauczyciela), studenci uniwersytetów, członkowie kolegiów doktorskich na uniwersytetach w Pradze i Wiedniu, ministerstwa, urzędnicy, członkowie Cesarskiej Akademii Nauk, bibliotekarze, a w przypadku szkół średnich ich uczniowie.

Wypożyczanie odbywało się po wpłaceniu odpowiednie kaucji w wysokości do 15 florenów. Osoby wypożyczające powinny przedstawić dokument upoważniający je do wypożyczenia książek poza bibliotekę. Przynajmniej dzień wcześniej należało złożyć w bibliotece rewers. Książki udostępniano na okres jednego miesiąca. Nie wypożyczano rękopisów, książek rzadkich i cennych, książek z księgozbioru podręcznego, słowników, kompendiów, czasopism, sprawozdań rocznych szkół średnich oraz beletrystyka. No- 
wości wydawnicze udostępniano dopiero po upływie dwóch miesięcy od ich nabycia, chyba, że zainteresowana osoba wpłaciła kaucję w wysokości ceny tej książki. ${ }^{52}$

Z zachowanych dokumentów bibliotecznych wynika, że udostępniano materiały biblioteczne również poza teren miasta. Przede wszystkim udostępniano w ten sposób sprawozdania szkolne lub specjalistyczne dzieła z księgozbioru nauczycielskiego. Wypożyczenia te nie były jednak zbyt częste, bowiem większy wybór książek posiadały biblioteki uniwersyteckie w Krakowie i Lwowie.

Wspomniany w instrukcji system rewersowy wprowadzono w bibliotece gimnazjalnej dość późno, bo dopiero w latach 1901-1903.

Biblioteka uczniowska dostępna była dla wszystkich uczniów dwa razy w tygodniu, po piątej godzinie lekcyjnej. Książki z biblioteki wypożyczał nauczyciel przy pomocy jednego z uczniów starszej klasy. Wszystkie wypożyczenia rejestrowano $w$ odpowiednim zeszycie. Podobnie było $z$ biblioteką dla nauczycieli, którą otwierano dwa razy w tygodniu, zawsze w środę i piątek między godziną trzynastą a czternastą. W okresie wakacji obie biblioteki były nieczynne i właśnie wtedy dokonywano skontrum.

W działającej przy bibliotece uczniowskiej od 1906 roku „Czytelni uczniów" udostępniano książki i czasopisma tylko prezencyjnie i tylko w niedzielę, bo tylko wtedy można było udostępnić dla niej zbiory biblioteki nauczycielskiej. Dopiero w latach trzydziestych otwierano ją codziennie, po zakończeniu lekcji. Od roku szkolnego 1938/1939 biblioteka uczniów otwierana była trzy razy w tygodniu, między godziną szesnastą a osiemnastą. Dopiero od momentu zatrudnienia stałego bibliotekarza w 1950 roku, bibliotekę otwierano codziennie.

\section{Podział biblioteki na nauczycielską i uczniowską}

Od początków istnienia szkoły aż do roku 1848 funkcjonowała w niej tylko jedna biblioteka. W roku 1848 zapoczątkowano istnienie biblioteki uczniów. Podział ten wprowadzono ze względów dydaktycznych i różnorodności gromadzonych przez oba działy zbiorów. Biblioteka nauczycielska gromadziła, bowiem dzieła naukowe, słowniki, encyklopedie, wydania klasyków literatury światowej, prace o profilu pedagogicznym, które miały stanowić warsztat pracy naukowej nauczyciel, chociażby z powodu obowiązku umieszczania rozpraw naukowych w sprawozdaniach szkolnych. Rozprawy te pod względem tematycznym obejmowały szeroki i różnorodny wachlarz tematów $\mathrm{z}$ rozmaitych dziedzin wiedzy. 
Również suplenci po ukończeniu studiów mieli obowiązek w ciągu trzech lat zdać tak zwany egzamin nauczycielski, który w części pisemnej przewidywał prace o charakterze interdysyplinarnym, zbliżonym do rozpraw ze sprawozdań szkolnych. Do napisania takiej pracy zapewne konieczne było wykorzystanie materiałów gromadzonych w bibliotekach szkół średnich.

Biblioteka uczniowska gromadziła przede wszystkim podręczniki szkolne, wydawnictwa popularnonaukowe, lektury i beletrystykę młodzieżową. Z założenia miała stanowić tylko księgozbiór pomocniczy i uzupełniający do nauki przedmiotów objętych planem nauczania jednocześnie rozwijając zainteresowania czytelnicze młodzieży.

\section{Zasób biblioteki}

W związku z faktem funkcjonowania biblioteki szkolnej od roku 1658 aż po rok 1965, kiedy to cały zbiór uległ rozproszeniu, trudno przyjąć jeden system klasyfikacji dla przeprowadzenia analizy zawartości księgozbioru. Za podstawę opisu przyjęto system klasyfikacji księgozbioru, według którego ułożony został drukowany katalog biblioteki nauczycielskiej z lat 1899 i $1900 .{ }^{53}$ Mniejszą uwagę zwrócono na podręczniki szkolne, szczególnie te z XIX i XX wieku, które omówił już Józef Świeboda. ${ }^{54}$ Oddzielnie zostanie omówiony zasób biblioteki uczniowskiej.

Zawartość biblioteki nauczycielskiej ujęto w piętnastu działach. Pierwszy z nich, „Bibliografia, dzieła o urządzaniu bibliotek i katalogi”, obejmuje tylko pięć pozycji. Wszystkie pochodzą z lat osiemdziesiątych XIX wieku, a wśród nich znajduje się Bibliografia polska Karola Estreichera zakupiona do biblioteki z pieniędzy fundacji Henryka Jakuba Kretschmera, Ludwika Finkla Bibliografia historii polskiej oraz Ferdynanda Grassauera Handbuch für österreichischen Bibliotheken.

W dziale „Filozofia i estetyka”, zaliczanym do jednego z większych, znajdują się dzieła z zakresu historii filozofii, opracowania ogólne dotyczące psychologii. Gromadzono również piśmiennictwo specjalistyczne, prace krytyczne dotyczące poszczególnych systemów filozoficznych, trendów w sztuce i estetyce oraz prace poszczególnych filozofów: Arystotelesa, Platona, Kanta, Schopenhauera.

Na szczególną uwagę zasługuje szesnaście starodruków pochodzących $\mathrm{z}$ tego działu:

- Friedricha Blankenburga Litterarische Zusätze zu Sulzers allgemeine The- 
orie der schönen Kunste. Lipsk 1796-1798, - Johanna Eschenburga Entwurf einer Theorie und Litteratur der schönen Wissenschaften. Berlin-Szczecin 1783,

- Johanna Federa Logik und Metaphysik. Getynga 1774 oraz drugie wydanie z 1786 ,

- Johanna Fichtego Versuch einer Kritik aller Offenbarung. Królewiec 1793 ,

- Emmanuela Kanta Grundlegung zur Metaphysik der Sitten. Graz 1796; Beobachtung über dem Gefühl des Schönen und Erhaben. Ryga 1771; Kritik der Urtheilskraft. Berlin 1799,

- M. Mangolda Philosophia recentior. Monachium 1763,

- Jana Morawskiego Totius philosophiae principia de ente communi explicata. Poznań 1682,

- Villaume'go Vom Vergnügen. Tübingen 1788,

- G. Zacharyasiewicza Krótki zbiór starożytnych moralistów. Łowicz 1784.

Dział trzeci to „Pedagogika i szkolnictwo”, w którym zgromadzono opracowania z historii pedagogiki i dydaktyki, poradniki dla nauczycieli, a wśród nich Jana Amosa Komeńskiego Orbis sensualium pictus z 1662 roku w wydaniu norymberskim. Większość stanowią dziewiętnastowieczne poradniki dla nauczycieli poszczególnych przedmiotów.

W dziale czwartym „Umiejętności religijne” zgromadzono pisma Ojców Kościoła np.: św. Augustyna Confessionum libri XIII wydane w Paryżu w 1645 roku,

- Beatyfikacje wielkiego stugi bożego Wincentego á Paulo. Kraków 1731, - Marii de Beaumont Amerykanki albo dowód religii chrześcijańskiej. Warszawa 1784,

- Jakoba Bossueta Exposition de la doctrina de L'eglise. Paryż 1791, - Mojżesza Mendelsohna Jerusalem oder über religiöse Macht und Judenthum. Berlin 1783.

Najliczniejsza spośród wszystkich działów jest „,Filologia klasyczna, archeologia, epigrafika". W jego skład wchodzą dzieła klasyków greckich i rzymskich: Ajschylosa, Ezopa, Arystotelesa, Sofoklesa, Platona, Homera, Katullusa, Cycerona, Horacego i wielu innych. Ponadto opracowania z zakresu historii literatury klasycznej, opracowania dotyczące poetyki, leksykologii, retoryki języków greckiego i łacińskiego, monografie dotyczące poszczególnych autorów, leksykony. 
Z zakresu archeologii i epigrafiki w księgozbiorze nauczycielskim znajdowało się znacznie mniej pozycji. Wśród cenniejszych należy wymienić: - Arystotelesa Organum z 1597 roku, - Arystotelesa Compendium librorum physicorum. Argentinae 1600, - Arystotelesa Tomus physicus. Francofurti 1594,

- Seneki Opera omnia. Lipsiae 1797-1811,

- Seneki Tragedye. Toruń 1696.

W dołączonym do działu „Filologia klasyczna” podrozdziale znajdują się książki z zakresu gramatyki, stylistyki i metryki języków greckiego i łacińskiego np. Emanuela Alvareza De institutione grammatica z 1777 roku wydane w Kaliszu, Stanisława Konarskiego Gramatyka lacińska z 1741 roku wydana w Warszawie oraz Marcelego Krausa Institutiones rhetoricae z 1687 roku wydane również w Warszawie.

Oddzielny dział obejmuje „Filologię nowoczesną”, w którym jednocześnie uwzględniono podział na języki: polski i inne słowiańskie oraz język niemiecki. W mniejszym stopniu gromadzono literaturę w innych językach.

W poddziale "Gramatyka i stylistyka" umieszczono m. in. podręczniki do języka polskiego i gramatyki polskiej np. Onufrego Kopczyńskiego Gramatykę języka polskiego z 1778 roku wydaną w Warszawie. Do cenniejszych pozycji można zaliczyć: Sebastian Klonowica Worekjudaszów wydany w 1607 roku w Krakowie, Stanisława Konarskiego O skutecznym rad sposobie wydane w Warszawie w 1760 roku, Ignacego Krasickiego Zbiory potrzebniejszych wiadomości wydane w 1781 roku we Lwowie i Samuela Twardowskiego Miscellanae selecta z 1682 roku wydane w Kaliszu.

Z zakresu filologii niemieckiej zbierano dzieła klasyków: Goethego, Schillera i Klopstocka zarówno w wersji oryginalnej, jak i w thumaczeniach na język polski. Poza tym opracowania i monografie poszczególnych dzieł i autorów. W poddziale „Gramatyka, stylistyka i poetyka” dołączonym do literatury niemieckiej znajdowały się opracowania z gramatyki i słowniki językowe. Literatura w innych językach reprezentowana jest przede wszystkim w formie thumaczeń polskich i niemieckich. Szczególnie cenne sq starodruki:

- Lodovica Ariosto Orlando szalony w thumaczeniu Piotra Kochanowskiego, wydany w 1799 roku w Krakowie,

- Benjamina Hedericha Känntniss der vornehmen Schriftsteller. Wittenberga 1767 ,

- Victora Hehna Gedanken über Goethe. Berlin 1789,

- Johanna Herdera Zwei Pressschriften. Berlin 1789, 
- Johanna Herdera Ideen zur Philosophie der Geschichte der Menschheit. Ryga - Lipsk 1785,

- Friedricha Klopstocka Oden. Wien 1784.

Dział „Lingwistyka” obejmuje swym zakresem dzieła dotyczące gramatyki porównawczej, słowniki oraz podręczniki i gramatyki do nauki sanskrytu. Najciekawsze pozycje to: Calepinusa Septem linguarum... Lexicon latimum wydany w Patavii w 1758 roku, Floriana Bobrowskiego Lexicon latino-polonicum drukowany w Wlinie w 1841 roku, Nomenclator czyli slownik $z$ polskiego na laciński wydany w Kaliszu w 1746 roku oraz Grzegorza Knapskiego Thesaurus Latino-Germanico-Polonus wydany w 1668 roku w Krakowie i Benjamina Hedericha Graecum Lexicon Manuale wydany w Lipsku i Londynie w 1796 roku.

Dział ósmy to „Geografa, etnografia i statystyka", zawiera głównie opisy podróży, korespondencje i dzieła treści ogólnej z zakresu geografii i etnografii, a wśród nich Geografię Galicji i Lodomerii wydaną w Przemyślu w 1786 roku, Listy różne z Azji, Afryki, Ameryki od misjonarzów Societatis Jesu przestane z 1756 roku, wydane w Warszawie, Jakoba Spona Voyage d'Italie, de Dalmatie, de Grece wydane w Amsterdamie w 1679.

Dzieła z zakresu historii podzielona na dwa działy, pierwszy z nich dotyczy historii powszechnej oraz nauk pomocniczych historii, drugi obejmuje tylko historię monarchii austriacko-węgierskiej i jej krajów. Oba tworzą obok działu „Literatura klasyczna” drugi, co do wielkości dział biblioteki nauczycielskiej. W dziale historycznym na uwagę zasługują:

- Aeneasa Andersona Geschichte der Brittischen Gesandschaft nach China in Jahren 1792-1794. Hamburg 1796,

- Anhang zu dem historischen Bildersaal, enthaltend die Geschichten, so sich wehrend Regierung Leopoldi I. in Europa hin und wieder zugetragen. Nürnberg 1699,

- Joannesa Boehmiusa Acta pactis oliviensis. Wrocław 1763, - Josepha Boelcke'go Nowy dykcyonarz historyczny albo historya skrócona od poczatków świata do naszych czasów. Warszawa 1783-1787,

- Jakoba Bossueta Uwagi nad historia powszechna. Warszawa 1772, - M. Chevreau Histoire du monde. Haga 1687.

Gromadzono również piśmiennictwo polskich historyków: Brücknera, Czackiego, Lelewela, Szczanieckiego dotyczące historii powszechnej.

Dział dziesiąty obejmuje historię monarchii austriacko-węgierskiej i przede wszystkim składa się z opracowań dotyczących historii Polski, w mniejszym stopniu historii Austrii. 
W dziale matematycznym, jednym z mniejszych w bibliotece gimnazjalnej znajdowały się niemieckie podręczniki szkolne i zaledwie kilka polskich. Najcenniejszą pozycją w tym dziale wydaje się być Andreasa Tacqueta Elementa geometriae planae et solidae wydane w Amsterdamie 1701 roku.

Dużo bogatszy jest dział Historia naturalna, gdzie obok dzieł ogólnych z zakresu zoologii i botaniki, gromadzono tablice i atlasy do nauki przyrody. W tym dziale znajduje się piętnastotomowe dzieło Georgesa Buffona $\mathrm{z}$ lat 1775-1776 Oeuvres completes wydane w Paryżu oraz siedmiotomowe Allgemeine Naturgeschichte z 1785 roku, dzieła Krzysztofa Kluka wydawane w końcu XVIII wieku.

Dział trzynasty Fizyka, chemia, astronomia, meteorologia obejmuje głównie pozycje popularnonaukowe dotyczące dziewiętnastowiecznych wynalazków, ogólne opracowania z zakresu chemii i fizyki. Ilościowo jest to najmniejszy dział biblioteki nauczycielskiej, podobnie jak „Ekonomia, górnictwo, leśnictwo i gospodarstwo domowe”. Ostatni z działów „Handel, komunikacja, przemysł" stanowią opracowania dotyczące handlu i przemysłu galicyjskiego.

Raz jeszcze potwierdza się, że biblioteka nauczycielska gromadziła przede wszystkim materiały o profilu zgodnym z profilem nauczania w gimnazjum klasycznym. Dlatego najlicznejszą grupę w księgozbiorze stanowiła literatura klasyczna i współczesna. Księgozbiór słabiej zaopatrzony był w książki z dziedziny nauk matematyczno-przyrodniczych.

Charakterystyczne dla wszystkich bibliotek szkolnych było to, że księgozbiór nauczycielski był zawsze liczebniejszy od uczniowskiego. W szkole rzeszowskiej bibliotekę uczniowską podzielono, ze względu na język gromadzonych publikacji, na niemiecka, polską i ruska. W ich zbiorach zgromadzone były podręczniki szkolne, zalecane lektury obowiązkowe i uzupełniające, dzieła literatury polskiej i w mniejszym stopniu literatura dla dzieci i młodzieży. Ten ostatni typ zbiorów usunięto z biblioteki w 1948 roku jako zbędny w bibliotece szkoły średniej.

W obu bibliotekach gromadzono również prasę codzienną fachową poświęconą szkolnictwu i dydaktyce, miesięczniki literackie dla lepszej orientacji w wydawanym asortymencie, miejscowe gazety informacyjne, periodyki naukowe.

Podsumowując należy stwierdzić, że zbiory biblioteki I Gimnazjum w Rzeszowie miały przede wszystkim charakter naukowy i pedagogiczny. Służyły nauczycielom jako warsztat pracy naukowej, jednocześnie umożliwiały podnoszenie kwalifikacji zawodowych, zapoznawały z osiągnięcia- 
mi naukowymi i nowymi metodami dydaktycznymi. Dla uczniów biblioteka była miejscem rozwijania zainteresowań czytelniczych i naukowych: "Czytała młodzież książki różne. Biblioteka gimnazjalna była spora. Zawierała arcydzieła polskich i obcych pisarzy. Nowości było mniej. Pochłaniali uczniowie Sienkiewicza, Prusa, Orzeszkowa, Dygasińskiego, Kraszewskiego, Kaczkowskiego i wielu innych. Młodzi chciwie czytali Mlodego wygnańca w opracowaniu Anczyca, książki Przyborowskiego, Maya..."wspomina Franciszek Januszewski, absolwent rzeszowskiego gimnazjum. ${ }^{55} \mathrm{Uzu}-$ pełnieniu wiadomości nabywanych w szkole służyła Czytelnia Uczniów. Miała budzić zainteresowania literaturą oraz zagadnieniami z innych dziedzin wiedzy. Korzystano $z$ niej także przy przygotowaniach do egzaminu dojrzałości.

\section{Zakończenie}

Biblioteka rzeszowskiej szkoły przez cały okres swojego istnienia spełniała tradycyjną usługową funkcję w stosunku do potrzeb nauczania. jej zasoby wykorzystywali zarówno uczniowie przygotowując się do zajęć szkolnych, egzaminów dojrzałości i późniejszych studiów uniwersyteckich, rozwijając swoje zainteresowania naukowe i literackie, jak i nauczyciele zapoznając się z nowymi metodami dydaktycznymi, osiągnięciami nauki, pisząc swoje prace naukowe i referaty do sprawozdań szkolnych.

Biblioteka służyła środowiskom pozaszkolnym jako placówka kulturalna, chociaż korzystały z niej wąskie kręgi użytkowników.

Gromadzeniem zbiorów w okresie autonomii Galicji zajmowało się grono pedagogiczne składające się w tym czasie w większości z Polaków. Decyzje grona nauczycielskiego były jednym ze środków kształtowania poglądów młodzieży, ich zainteresowań naukowych i literackich. Szczególny nacisk kładziono na poznawanie literatury, historii i kultury ojczystej. Szkoła i biblioteka miały swój wkład w wykształcenie wielu uczonych, artystów, ludzi przemysłu, bowiem jeszcze w czasie nauki w szkole dzięki namowie pasjonatów prowadzących zajęcia i biblioteki szkolne, uczniowie korzystali ze zbiorów bibliotecznych, bogatego gabinetu przyrodniczego i zbiorów muzeum etnograficznego. Poznawali w ten sposób kulturę i historię Rzeszowa i jego okolic. Ważną formą działalności Czytelni Uczniów było uczestnictwo szkoły w życiu kulturalnym miasta. Rzeszów w tym czasie nie posiadał własnego teatru, dlatego organizowane przez szkołę i opiekunów bi- 
bliotek wieczorki literackie i przedstawienia teatru szkolnego wypełniały tę lukę w życiu miasta.

Biblioteka była także terenem pracy społecznej. Uczniowie starszych klas pełnili dyżury pomagając prowadzącemu bibliotekę nauczycielowi przy wypożyczaniu książek, ich oprawianiu i konserwacji.

Najlepiej o bibliotece I Gimnazjum świadczą opinie Franciszka Radziszewskiego i Heleny Falkowskiej, którzy zaliczali bibliotekę do jednej z większych bibliotek szkolnych w Polsce zarówno pod względem zasobu, jak czytelnictwa.

Praca ta nie oddaje w pełni historii tego księgozbioru ani jego zasobu, co w dużej mierze wynika $\mathrm{z}$ braku archiwaliów z okresu pijarskiego oraz $\mathrm{z}$ rozproszenia księgozbioru po 1965 roku, co spowodowało zniknięcie kilku wartościowych pozycji, pogorszenie stanu zachowania zbioru, szczególnie 144 starodruków należących niegdyś do biblioteki gimnazjalnej, a obecnie przechowywanych w Bibliotece Głównej WSP w Rzeszowie.

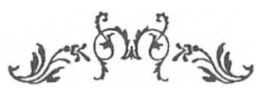

Przypisy:

' Świeboda Józef, Poczqlki kolegium Pijarów w Rzeszowie [W:] Malopolskie Studia Historyczne. Kraków 1964, R. VI, z. 3-4; tenże, Dzieje I Gimnazjum w Rzeszowie 1786-1918. Rzeszów 1984 oraz Collegium Ressoviense w życiu Polaków 1658-1983. Rzeszów 1983. ${ }^{2}$ Adamowski Mieczysław, Biblioteka Nauczycielska ,starego " gimnazjum w Rzeszowie [W:] Rocznik Województwa Rzeszowskiego. Rzeszów 1959, R. 1, z. 2.

${ }^{3}$ Wojewódzkie Archiwum Państwowe Rzeszów, Zespół Akt I Gimnazjum nr 214, sygn. 638.

${ }^{4}$ Historia Domus Ressoviensis... 1700-1783. Rkps 1843, Biblioteka Muzeum Czartoryskich, Kraków; Buba Jan, Pijarzy w Polsce [W:] Nasza Przeszlość, t. XV (1962).

${ }^{5}$ Historia primitiva provinciae Poloniae Scholarum Piarum a.d. 1823, rkps 40 Biblioteka oo. Pijarów w Krakowie.

'Świeboda Józef, Początki..., s. 127.

${ }^{7}$ Archivio Generalitio Scholarum Piarum Rzym, Reg. 57, Prov. Pol., 3 Ress. dok. nr 20.

' Sprawozdanie Dyrekcji l Gimnazjum za rok szk. 1938/1939, WAP Rzeszów, ZAlG nr 214, sygn. 433 i 451.

${ }^{9}$ Podaję za Józefem Świebodą: AGSP Rzym, Reg. 57, Prov. Pol., 3 Ress. „Catalogus Librorum Domus Ressoviensis Anno 1696"; Radziszewski Franciszek, Wiadomość historyczno-statystyczna o znakomitszych bibliotekach... Kraków 1875, s. 73

${ }^{10}$ Konarski Stanisław, Ustawy szkolne, s.262-263; Falkowska Helena, Z dziejów polskich bibliotek szkolnych. Warszawa 1966, s.9-11

" WAP Rzeszów, ZAIG nr 214, sygn. 628. 
12 Sprawozdanie Dyrekcji C.K. Wyższego Gimnazjum w Rzeszowie za rok 1885/1886: Świstuń Filip, Kronika Gimnazjum Rzeszowskego, s. 3-49

${ }^{13}$ Biblioteka Czartoryskich Kraków: Historia Domus Ressoviensis...1702-1783, rkps 1843

${ }^{14}$ Świstuń Filip, op. cit., s. 25.

${ }^{15}$ Adamowski Mieczysław, op. cit., s. 105-112

${ }^{16}$ Leniek Jan, Księdza Izydora Chróścińskiego Kronika... [W:] Archiwum dla dziejów literatury i oświaty w Polsce. Kraków 1897, t. IX, s. 320-330.

${ }^{17}$ WAP Rzeszów, ZAIG nr 214, sygn. 216: Polecenie Gubernium z dnia 20 września 1842 roku L. 60645 i protokół dyrektora z dnia 22 września 1842 roku L. 162: Verzeichniß der alten Bücher Sammlung des Rzeszower Gymnasium.

${ }^{18}$ WAP Rzeszów, ZAIG nr 214, sygn. 354: Protokół przejęcia rzeszowskiego Gimnazjum od prefekta Melichera przez prefekta Viditza w roku 1829, sygn. 355: Inwentarz z roku 1830 podpisany przez Viditza, sygn. 216: Verzeichniß der alten Bücher. Sammlung des Rzeszower Gymnasium.

${ }^{19}$ Adamowski Mieczysław, op. cit., s. 105-112

${ }^{20}$ WAP Rzeszów, ZAIG nr 214, sygn. 531: Kwestionariusz z 22 lutego 1926 roku., L. 89 i z 17 grudnia 1925 r., L. 348.

${ }^{21}$ Świeboda Józef, Srodki materialne oo. Pijarów w wieku XVII-XVIII [W:] Wklad pijarów do nauki i kultury w Polsce XVII-XVIII wieku. Praca zbiorowa pod red. Ireny Stasiewicz-Jasiukowej. Warszawa, Kraków 1993, s. 205-218.

${ }^{22}$ WAP Rzeszów, ZAIG nr 214, sygn. 371: Rozporządzenie cesarza z 13 lutego 1811 roku W sprawie zakupu książek pomocniczych dla biblioteki. Ordinationes Scholasticae 18101830

${ }^{23}$ WAP Rzeszów, ZAlG nr 214, sygn. 371: Dekret Nadwornej Komisji Naukowej z dnia 21 kwietnia 1816 r. i z 6 czerwca 1816 r. Ordinationes Scholasticae 1810-1830.

${ }^{24}$ WAP Rzeszów, ZAIG nr 214, sygn.217.

${ }^{25}$ Sprawozdanie Dyrekcji C.K. Gimnazjum w Rzeszowie za rok szkolny 1850/1851.

${ }^{26}$ WAP Rzeszów, ZAIG nr 214, sygn.217: „Vorschrift über das Ausleihen der Bücher aus Universitäts- und Liceal-Bibliotheken" z 1850 roku.

${ }^{27}$ Janelli Marian, Missona Kazimierz, Zbiór ustaw i rozporzq̨dzeń odnoszacych się do szkól średnich w Galicji. Lwów 1918: Ustawa zasadnicza z dnia 21 grudnia 1867 roku, Dz. U.P. nr 142 ,Zbiory środków naukowych".

${ }^{28}$ lbidem, $\$ 55.5$.

${ }^{29}$ Kopia Henryk, Ustawy i rozporzqdzenia obowiqzujace w galicyjskich szkolach średnich. Lwów 1900, s. 203-204: Rozporządzenie M.W.i O. z 16 grudnia 1885 r., L. 23324.

${ }^{30}$ Ibidem, s. 203-204: Rozporządzenie RSK z 18 stycznia 1872, L. 6109,

${ }^{3 !}$ Sprawozdanie Dyrekcji C.K. Wyższego Gimnazjum w Rzeszowie za rok szkolny 1905/1906.

${ }^{32}$ Falkowska Helena, op.cit., s. 47-55.

${ }^{33}$ Kuratorium Oświaty i Wychowania w Rzeszowie. Polecenie nr KOS II-2/2/60.

${ }^{34}$ Swieboda Józef, Collegium Ressoviense..., s. 78.

${ }^{35}$ Orzech Jadwiga, Poczatki i rozwój Biblioteki Gtównej WSP w Rzeszowie [W:] Rola i funkcje bibliotek WSP w Polsce. Rzeszów 1992.

${ }^{36}$ Konarski Stanisław, Ustawy szkolne. Kraków 1925, s. 46 i n.

${ }^{37}$ WAP Rzeszów, ZAIG nr214, sygn. 363. 
38 WAP Rzeszów, ZAIG nr 214, sygn. 223: Pismo Magistratu Miasta Rzeszowa z dnia 5 maja 1887 roku, L. 2471.

${ }^{39}$ WAP Rzeszów, ZAIG nr 214, sygn. 216.

40 WAP Rzeszów, ZAIG nr 214, sygn. 217.

${ }^{41}$ Polecenie RSK $z$ dnia 17 listopada 1888 r., L. 16 315. Okólnik C.K. RSK [W:] Muzeum R. 30,1914 , s. 133.

42 Sprawozdanie C.K. Wyższego Gimnazjum w Rzeszowie: Okólnik L. 1352 z roku 1896/1897.

${ }^{43}$ Sprawozdanie Dyrekcji C.K. Wyższego Gmnazjum w Rzeszowie za rok szkolny 1899/1900: „Wykaz ksiażek znajdujących się w bibliotece nauczycielskiej rzeszowskiego gimnazjum do końca roku 1899/1900 zestawit... profesor E. Roszka".

${ }^{44}$ Zawartość treściową działów czternastego, piętnastego ustalono na podstawie innych materiałów archiwalnych. Być może wprowadzenie tych działów uwzględnione było w zaleceniach ministerialnych, a w bibliotece rzeszowskiego gimnazjum nie było w ogóle dzieł o takiej treści.

${ }^{45}$ WAP Rzeszów, ZAIG nr 214, sygn. 359.

46 WAP Rzeszów, ZAlG nr 214, sygn. 441 i 597.

${ }^{47}$ WAP Rzeszów, ZAIG nr 214, sygn. 531: Kwestionariusz z 22 lutego 1926 r., L. 89 oraz Kwestionariusz z 17 grudnia 1925 roku, L. 348. Oba przesłane przez Departament Nauki i Szkół Wyższych w Min. W.R. i O.P.

${ }^{48}$ WAP Rzeszów, ZAIG nr 214, sygn. 359: Zarządzenie C.K. RSK, L. 22505.

${ }^{49}$ WAP Rzeszów, ZAIG nr 214, sygn. 594.

${ }^{50}$ Dziennik Urzędowy Min.W.R. i O.P. z 1925 r., nr 11, poz. 103.

${ }^{51}$ Świeboda Józef , Collegium ressoviense..., s. 15.

52 WAP Rzeszów, ZAIG nr 214, sygn. 217: Vorschrift über das Ausleihen der Bücher in Universitäts- und Lyceal-Bibliotheken.

${ }^{53}$ Sprawozdanie Dyrekcji C.K. Wyższego Gimnazjum w Rzeszowie za rok szkolny 1899/1900.

${ }^{54}$ Świeboda Józef, Dzieje I Gimnazjum..., s. 58-59, 153-159.

${ }_{55}$ Januszewski Franciszek, Wspomnienia o Gimnazjum w Rzeszowie (lata 1905-1913)

[W:] Szkola charakterów: księga jubileuszowa I Gimnazjum i Liceum w Rzeszowie. Oprac. Józef Świeboda. Rzeszów 1985, s. 80-92. 